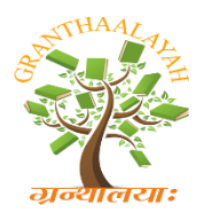

$$
\begin{aligned}
& \text { INTERNATIONAL JOURNAL OF RE } \\
& \text { GRANTHAALAYAH } \\
& \text { A knowledge Repository }
\end{aligned}
$$

Science

\title{
USE OF INDUSTRIES BYPRODUCT AS AN ALTERNATIVE LIQUID FERTILIZER IN SOILLESS CULTURE AND ITS EFFECT ON SWEET PEPPER
}

\author{
Md. Jahedur Rahman *1, Md. Shahjahan Ali ${ }^{2}$ \\ ${ }^{* 1}$ Professor, Department of Horticulture, Sher-e-Bangla Agricultural University, Dhaka, \\ Bangladesh \\ ${ }^{2} \mathrm{PhD}$ Fellow, Department of Horticulture, Sher-e-Bangla Agricultural University, Dhaka, \\ Bangladesh
}

\begin{abstract}
There is a gaining interest in reducing the production cost of agricultural crops. Salt industries byproduct (SIB) can reduce production cost as it is a cheaper fertilizer source. SIB is the effluent of salt industries. But there is no research on its effects in agricultural crop production in Bangladesh. Therefore, it is important to identify the dose of SIB in sweet pepper/capsicum in Bangladesh. In this study, growth and yield parameters in sweet pepper by applying different doses of SIB were investigated. Five concentrations of salt industries byproduct (SIB) are considered as treatments, viz. $\mathrm{S}_{1}=3 / 4$ strength Rahman and Inden (2012) $+0 \mathrm{ml} . \mathrm{L}^{-1} \mathrm{SIB}, \mathrm{S}_{2}=3 / 4$ strength Rahman and Inden (2012) + $0.25 \mathrm{ml} . \mathrm{L}^{-1} \mathrm{SIB}, \mathrm{S}_{3}=3 / 4$ strength Rahman and Inden (2012) $+0.5 \mathrm{ml} . \mathrm{L}^{-1} \mathrm{SIB}$, $\mathrm{S}_{4}=3 / 4$ strength Rahman and Inden $(2012)+0.75 \mathrm{ml} \cdot \mathrm{L}^{-1} \mathrm{SIB}$ and $\mathrm{S}_{5}=3 / 4$ strength Rahman and Inden $(2012)+1.0 \mathrm{ml} . \mathrm{L}^{-1} \mathrm{SIB}$. Different concentrations of salt industries by product showed significant variation in most of the parameters. The highest plant height, the maximum number of fruit/plants, individual fruit weight, fruit length, fruit diameter, fruit volume, and yield were found highest in $\mathrm{S}_{3}$. But all the parameters were drastically reduced when $\mathrm{S}_{5}$ treatment was applied. Therefore, $S_{3}$ treatment can be used for sweet pepper cultivation in soilless culture system in Bangladesh.
\end{abstract}

Keywords: Salt Industries Byproduct; Hydroponics; Fruit Quality; Yield \& Sweet Pepper.

Cite This Article: Md. Jahedur Rahman, and Md. Shahjahan Ali. (2020). "USE OF INDUSTRIES BYPRODUCT AS AN ALTERNATIVE LIQUID FERTILIZER IN SOILLESS CULTURE AND ITS EFFECT ON SWEET PEPPER." International Journal of Research - Granthaalayah, 8(2), 218-227. https://doi.org/10.29121/granthaalayah.v8.i2.2020.210.

\section{Introduction}

Sweet pepper (Capsicum annum L.) is a flowering plant under the genus Capsicum and belongs to the family Solanaceae. In Bangladesh it is commonly known as capsicum. It is relatively non- 
pungent with thick flesh and is the world's second most important vegetable after tomato (AVRDC, 1989). Brazil is thought to be the original home of pepper (Shoemaker and Teskey, 1995). Capsicum can be considered a functional food, because it contains many health-promoting phytochemicals such as vitamins A, B, C, E, phenolic compounds, carotenoids, and capsaicin (Bloch and Thomson, 1995). These compounds are reported to have antioxidant, anticarcinogenic, antimutagenic, anti-aging, and antibacterial properties (Chu et al., 2002; Surh, 2002). In addition to their role in defense against human diseases, antioxidants have an important role in plant defense and are produced in response to both biotic and abiotic stresses (Sakihamaet al., 2002; Slater et al., 2003).

There is increasing attention being given toward reducing the production cost of agricultural crops. Salt industries byproduct can reduce production cost as it contains many macronutrients, especially calcium $\left(\mathrm{Ca}^{2+}\right)$, magnesium $\left(\mathrm{Mg}^{2+}\right)$, and micronutrients. Salt industries byproduct is the effluent of salt industries and cheaper than commercial fertilizers. Salt industries byproduct contains sodium $\left(\mathrm{Na}^{+}\right)$that may impose mild salinity, but it also contains some silicon ( $\mathrm{Si}$ ) that may minimize the negative effects of salinity. Bradbury and Ahmad (1990) and Liang et al. (1996) reported that Si minimized the adverse effects of salinity. $\mathrm{Ca}^{2+}$ plays a key role in plant growth and fruit development and is involved in many biochemical and physiological processes (Saure, 2005). Significant economic losses of horticultural crops have been linked to inadequate $\mathrm{Ca}^{2+}$ nutrition (Grattan and Grieve, 1999). Salt industries byproduct can supply adequate $\mathrm{Ca}^{2+}$ and other micronutrients to sweet peppers. Thus, it can reduce fertilizer input and make agricultural practices more sustainable. However, there has been no research on salt industries byproduct application effects on crop production. Therefore, the present research work was aimed to study with the following objectives:

- To evaluate the effect of salt industries byproduct on growth and yield of capsicum, and

- To identify the suitable dose of salt industries byproduct in soilless capsicum.

\section{Materials and Methods}

Experimental Site: The experiment was conducted in the greenhouse at the Horticulture Farm of Sher-e-Bangla Agricultural University, Dhaka, Bangladesh from September 2015 to March 2016. The experiment was carried out during rabi season. The location of the study site is situated between $23{ }^{0} 41 / \mathrm{N}$ latitude and $90^{\circ}$ 22/ E longitude (Anon., 1989). The altitude of the location was $8 \mathrm{~m}$ from the sea level (The Meteorological Department of Bangladesh, Agargaon, Dhaka).

Plant Materials: Sweet pepper cv. 'Wonder Bell' of average fruit weight around $220 \mathrm{~g}$ was used in this experiment. Seeds of sweet pepper were collected from Siddique Bazar Seed Market, Dhaka. The salt industries byproduct was collected from Nitaigonj, Narayanganj.

Experimental Environment: The seeds were sown in the seed bed prepared by the media mixture of coco peat, brick broken and rice husk at the ratio of 6:2:2(v/v). Two-week-old seedlings were transferred into the $250-\mathrm{mL}$ plastic pots. Eight-week-old seedlings were transferred $20-\mathrm{cm}$ apart into the cork-sheet boxes containing media mixtures of coco peat, brick broken and rice husk at the ratio of $6: 2: 2(\mathrm{v} / \mathrm{v})$. The $150-\mathrm{cm} \times 25-\mathrm{cm} \times 30-\mathrm{cm}$ cork sheet boxes were prepared by corksheets. The boxes were filled with the media mixture of coco peat, brick broken and rice husk at 
the ratio of $6: 2: 2(\mathrm{v} / \mathrm{v})$. Six healthy seedlings were transferred in each box. The $\mathrm{pH}$ and EC of 6.0 and $2.5-3.5 \mathrm{dS} \cdot \mathrm{m}^{-1}$, respectively are maintaining in the nutrient solution.

Experimental Design and Treatments: The experiment was conducted in a completely randomized block design with three replications. Five concentrations of salt industries byproduct (SIB) are considered as treatments, viz.

$\mathrm{S}_{1}=3 / 4$ strength Rahman and Inden $(2012)+0 \mathrm{ml} \cdot \mathrm{L}^{-1} \mathrm{SIB}$, $\mathrm{S}_{2}=3 / 4$ strength Rahman and Inden $(2012)+0.25 \mathrm{ml}^{-L^{-1}} \mathrm{SIB}$, $\mathrm{S}_{3}=3 / 4$ strength Rahman and Inden $(2012)+0.5 \mathrm{ml} . \mathrm{L}^{-1} \mathrm{SIB}$, $\mathrm{S}_{4}=3 / 4$ strength Rahman and Inden $(2012)+0.75 \mathrm{ml}^{-L^{-1}} \mathrm{SIB}$ and $\mathrm{S}_{5}=3 / 4$ strength Rahman and Inden $(2012)+1.0 \mathrm{ml} . \mathrm{L}^{-1}$ SIB.

The nutrient compositions of Rahman and Inden (2012) solution were $\mathrm{NO}_{3}-\mathrm{N}, \mathrm{P}, \mathrm{K}, \mathrm{Ca}, \mathrm{Mg}$, and $\mathrm{S}$ of $17.05,7.86,8.94,9.95,6.0$ and $6.0 \mathrm{meq} \cdot \mathrm{L}^{1}$, respectively. The rates of micronutrients were Fe, $\mathrm{B}, \mathrm{Zn}, \mathrm{Cu}, \mathrm{Mo}$ and $\mathrm{Mn}$ of 3.0, 0.5, 0.1, 0.03, 0.025 and $1.0 \mathrm{mg} \cdot \mathrm{L}^{-1}$, respectively for the nutrient solutions.

Growing Media Preparation for Seedling Rising: The mixture of coco peat, broken bricks (khoa) and ash at the ratio of 50:30:20\% (v/v). Coco peat was soaked in a big bowl for 24 hours. It was washed well with water and spread in a polythene sheet for 3 hours. Then they are mixed with khoa and ash properly. This mixer was placed in a Styrofoam sheet box for using seedbed.

Seed Sowing: The seeds were soaked in water for 24 hours and then wrapped with piece of thin cloth. The socked seed were then spread over polythene sheet for 2 hours to dry out the surface water. After that seeds were sown in growing substrate and covered newspaper under room temperature for rising

Transplanting of Sweet Pepper Seedling: Sweet pepper seedlings were transplanted into the pots containing media mixtures mixture of coco peat, khoa and ash. Healthy capsicum seedlings were selected for transplanting. Capsicum plants were transplanted carefully so that roots were not damaged. After transplanting of capsicum plant in the pots light watering was done with sprayer.

Data Collection: Data were collected on different growth and yield components, viz., plant height at different days after planting, fruit length, fruit diameter, fruit volume, number of fruits per plant, individual fruit weight and fruit yield per plant.

Statistical Analysis: Data were analyzed by one-way analysis of variance (ANOVA) using SPSS software and the differences among means were determined using Tukey's test at 5\% level of probability.

\section{Results and Discussion}

Plant Height: Plant heights at different days after planting (DAT) of sweet pepper were significantly affected by different SIB concentrations. The highest plant heights at 30 DAT, 60 DAT, 90 DAT, 120 DAT, 150 and 180 DAT were found in the $S_{3}(3 / 4$ strength Rahman and Inden 
$\left.(2012)+0.5 \mathrm{mlL}^{-1} \mathrm{SIB}\right)$ treatment (Table 15). Meanwhile, the lowest plant heights were found in $\mathrm{S}_{5}$ (3/4 strength Rahman and Inden $\left.(2012)+1.0 \mathrm{mlL}^{-1} \mathrm{SIB}\right)$ treatment (Table 1). This result revealed that the greater plant height was found in the $S_{3}$ treatment compared to others. However, the mechanism for improvement of plant height due to application of $\mathrm{S}_{3}$ treatments not clear, but the positive impact of SIB is due to the presence of rather high amounts of $\mathrm{Ca}^{2+}$ and $\mathrm{Si}$, which might have contributed to reduce $\mathrm{Na}^{+}$absorption sites. Bradbury and Ahmad (1990) and Liang et al. (1996) reported that $\mathrm{Si}$ minimized the effects of salinity in Prosopis julifloraand barley, respectively. Calcium sulfate counteracted the toxic effect of $\mathrm{NaCl}$, resulting in greater plant height and leaf number of salts treated Leucaena leucocephalaplant (Hansen and Munns, 1988). Salt industries byproduct (SIB) contains a higher amount of $\mathrm{Ca}^{2+}$ which may able to counteract the toxic effects of $\mathrm{Na}^{+}$when applied at the rate of $1.0 \mathrm{mlL}^{-1}$.

Number of Fruit Per Plant: Significant variation was observed among $S_{1}, S_{2}, S_{3}, S_{4}$ and $S_{5}$ treatments in terms of number of fruits per plant (Figure 1). The maximum number of fruits per plant (9.0) was found in $S_{3}$ whereas the lowest (3.0) was found in $S_{5}$ treatment (Figure 2). The plants required optimum nutrient combination for proper growth and development. Probably $\mathrm{S}_{3}$ treatment provided $\mathrm{Ca}^{2+}$ which decrease $\%(\mathrm{BER})$ on the contrary $\mathrm{S}_{5}$ treatment contain more $\mathrm{Ca}^{2+}$ than $\mathrm{S}_{3}$ treatment which causes osmotic stress, resulting higher (\%) BER. Water stress and osmotic stress reduce $\mathrm{Ca}^{2+}$ transport particularly to the distal end region of sweet pepper fruit, where BER develops (Marcelis and Ho, 1999; Silber et al., 2005). Due to lower \% (BER) higher number of fruits found in $\mathrm{S}_{3}$ treatment.

Individual Fruit Weight: Individual fruit weight of capsicum varied significantly by different SIB concentrations. Result revealed that the biggest fruit $(210 \mathrm{~g})$ was recorded from $\mathrm{S}_{3}$ treatment whereas $\mathrm{S}_{5}$ treatment was scored as the lowest $(182 \mathrm{~g}$ ) at final harvest (Figure 2). This might be because of proper supply of nutrient in the plants. Shinohara et al. (1978) stated that sweet pepper growth was affected by different strength of nutrient solutions. The present finding was consisted with the findings of Shinohara et al. (1978). In the present study, $S_{3}$ can supply proper amount in available forms of nutrients to the plants resulting higher fruit weight.

Fruit Length: The maximum fruit length $(8.90 \mathrm{~cm})$ of capsicum was found in $S_{3}(3 / 4$ strength Rahman and Inden (2012) + $0.5 \mathrm{mlL}^{-1} \mathrm{SIB}$ ) treatment (Figure 3). Meanwhile the lowest value $(4.90 \mathrm{~cm})$ was found in $\mathrm{S}_{5}\left(3 / 4\right.$ strength Rahman and Inden $\left.(2012)+1.0 \mathrm{mlL}^{-1} \mathrm{SIB}\right)$ treatment. Similar findings on pepper plants were reported by Navarro et al. (2002).

Fruit Diameter: Fruit diameter of capsicum exposed statistically significant inequality for the application of salt industries byproducts. The maximum fruit diameter $(7.6 \mathrm{~cm})$ was recorded from $\mathrm{S}_{3}(3 / 4$ Rahman and Inden $(2012)+0.5 \mathrm{ml}$ of SIB $)$ treatment and the minimum fruit diameter $(4.5 \mathrm{~cm})$ was obtained from $\mathrm{S}_{5}(3 / 4$ Rahman and Inden $(2012)+1.0 \mathrm{ml}$ of SIB) treatment (Figure 4). Similar findings on pepper plants were reported by Navarro et al. (2002).

Fruit Volume: Significant difference was not found in fruit diameter due to the application of different strength nutrient solutions with salt industries by product. The highest fruit volume (228 cc) was recrded from $S_{3}(3 / 4$ Rahman and Inden (2012) $+0.5 \mathrm{ml}$ of SIB) treatment. Meanwhile, the lowest fruit volume $(185 \mathrm{cc})$ was obtained from $\mathrm{S}_{5}(3 / 4$ Rahman and Inden $(2012)+1.0 \mathrm{ml}$ of SIB) (Figure 5). Salinity reduces total yield by a fruit size reduction (Chartzoulakis and Klapaki, 2000). 
Plant Fresh Weight: The maximum plant fresh weight $(170 \mathrm{~g})$ was recorded from of $\mathrm{S}_{3}(3 / 4$ Rahman and Inden $(2012)+0.5 \mathrm{ml}$ of SIB) treatment while, the minimum plant fresh weight $(110 \mathrm{~g})$ was found from $\mathrm{S}_{5}(3 / 4 \mathrm{Rahman}$ and Inden $(2012)+1.0 \mathrm{ml}$ of SIB) treatment (Figure 6). Kaya et al. (2009) reported that increased salinity decreased fresh weight. In treatment $S_{5}$ salinity increased resulting decreased fresh weight.

Plant Dry Weight: Plant dry weights of capsicum were varied significantly by five treatments (Table 2). The highest dry weights of leaf stem and root was found in $S_{3}$ treatment. Meanwhile, dry weights of plants drastically decreased at $S_{5}$. This might be due to proper supply of nutrient solution to the plants. $S_{2}$ treatment containing higher $\mathrm{Ca}^{2+}$ which contributed to higher dry weights. On the contrary, $\mathrm{S}_{5}$ treatment contain highest amount of $\mathrm{Ca}^{2+}$ compared to other treatments, but it has salinity stress resulting lower dry weight. Epstein and Bloom (2005) reported that $\mathrm{Ca}^{2+}$ increased the root dry weight and calcium content in plant tissues. The present findings consisted with the other findings.

Yield: Marketable yield was affected by SIB concentrations (Figure 7). The highest yield (2.3 $\mathrm{kg} / \mathrm{plant})$ was found in $\mathrm{S}_{2}(3 / 4$ Rahman and Inden $(2012)+0.5 \mathrm{ml} \mathrm{SIB})$ treatment while, the lowest yield $(0.90 \mathrm{~kg} / \mathrm{plant})$ was found in $\mathrm{S}_{5}(3 / 4 \mathrm{Rahman}$ and Inden $(2012)+1.0 \mathrm{ml}$ of SIB) treatment. This might be due to higher number of fruits by application of $S_{3}$. Furthermore, SIB contains Si that might have a positive effect on fruit yield in sweet pepper. Stamatakis et al. (2003) found a positive effect of Si addition to the nutrient solution under saline condition in tomato fruit yield. Alexander and Clough (1998) also observed that marketable yield of pepper increased due to increased $\mathrm{Ca}^{2+}$, mainly because of decrease in BER-affected fruits.

In conclusion, plant growth and yield contributing characters were higher when applied $3 / 4$ Rahman and Inden (2012) + $0.5 \mathrm{ml} . \mathrm{L}^{-1} \mathrm{SIB}$. Therefore $3 / 4$ Rahman and Inden (2012) $+0.5 \mathrm{ml}$.LSIB can be applied in capsicum with high yield in minimum cost of production.

Table 1: Effect of salt industries by-product on plant height $(\mathrm{cm})$ at different days after transplanting of capsicum

\begin{tabular}{|l|c|c|c|c|c|c|}
\hline \multirow{2}{*}{ Treatments } & \multicolumn{6}{|c|}{ Plant height $(\mathrm{cm})$ at different days after transplanting (DAT) } \\
\cline { 2 - 7 } & 30 DAT & 60 DAT & 90 DAT & 120 DAT & 150 DAT & 180 DAT \\
\hline S1 & $41 \mathrm{c}^{\mathrm{z}}$ & $60 \mathrm{c}$ & $74 \mathrm{c}$ & $86 \mathrm{c}$ & $91 \mathrm{c}$ & $98 \mathrm{c}$ \\
\hline S2 & $47 \mathrm{~b}$ & $66 \mathrm{~b}$ & $79 \mathrm{~b}$ & $90 \mathrm{~b}$ & $96 \mathrm{~b}$ & $101 \mathrm{~b}$ \\
\hline S3 & $53 \mathrm{a}$ & $75 \mathrm{a}$ & $84 \mathrm{a}$ & $95 \mathrm{a}$ & $102 \mathrm{a}$ & $112 \mathrm{a}$ \\
\hline S4 & $37 \mathrm{~d}$ & $55 \mathrm{~d}$ & $65 \mathrm{~d}$ & $80 \mathrm{~d}$ & $87 \mathrm{~d}$ & $92 \mathrm{~d}$ \\
\hline S5 & $33 \mathrm{e}$ & $50 \mathrm{e}$ & $60 \mathrm{e}$ & $76 \mathrm{e}$ & $81 \mathrm{e}$ & $86 \mathrm{e}$ \\
\hline P & 0.001 & 0.001 & 0.001 & 0.001 & 0.001 & 0.001 \\
\cline { 2 - 7 } & $*$ & $* *$ & $*$ & $* *$ & $* *$ & $*$ \\
\hline
\end{tabular}

zMeans with different letter is significantly different by Tukey's test at $\mathrm{P} \leq 0.05$. P represents the level of significance of one-way ANOVA. ** significant at $\mathrm{P} \leq 0.01$. $*$ significant at $\mathrm{P} \leq 0.05$. SIB:

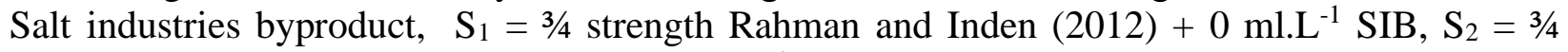
strength Rahman and Inden (2012) + $0.25 \mathrm{ml} . \mathrm{L}^{-1} \mathrm{SIB}, \mathrm{S}_{3}=3 / 4$ strength Rahman and Inden (2012) $+0.5 \mathrm{ml} . \mathrm{L}^{-1} \mathrm{SIB}, \mathrm{S}_{4}=3 / 4$ strength Rahman and Inden $(2012)+0.75 \mathrm{ml}^{-\mathrm{L}^{-1}}$ SIB and $\mathrm{S}_{5}=3 / 4$ strength Rahman and Inden (2012) + $1.0 \mathrm{ml} . \mathrm{L}^{-1} \mathrm{SIB}$ 
Table 2: Effect of salt industries byproduct on plant dry weight of capsicum.

\begin{tabular}{|l|c|c|c|}
\hline \multirow{2}{*}{ Treatments } & \multicolumn{3}{|c|}{ Plant dry weight (g/ plant) } \\
\cline { 2 - 4 } & Leaf & Stem & Root \\
\hline S1 & $7.98 \mathrm{c}^{\mathrm{z}}$ & $10.1 \mathrm{c}$ & $5.2 \mathrm{c}$ \\
\hline S2 & $9.2 \mathrm{~b}$ & $12.3 \mathrm{~b}$ & $6.1 \mathrm{~b}$ \\
\hline S3 & $10.5 \mathrm{a}$ & $15.2 \mathrm{a}$ & $8.5 \mathrm{a}$ \\
\hline S4 & $6.2 \mathrm{~d}$ & $8.5 \mathrm{~d}$ & $4.2 \mathrm{~d}$ \\
\hline S5 & $5.3 \mathrm{e}$ & $6.9 \mathrm{e}$ & $3.4 \mathrm{e}$ \\
\hline P & 0.007 & 0.001 & 0.003 \\
\cline { 2 - 4 } & $* *$ & $* *$ & $* *$ \\
\hline
\end{tabular}

zMeans with different letter is significantly different by Tukey 's test at $\mathrm{P} \leq 0.05$. $\mathrm{P}$ represents the level of significance of one-way ANOVA. ** significant at $\mathrm{P} \leq 0.01$. SIB: Salt industries byproduct, $\mathrm{S}_{1}=3 / 4$ strength Rahman and Inden $(2012)+0 \mathrm{ml} . \mathrm{L}^{-1} \mathrm{SIB}, \mathrm{S}_{2}=3 / 4$ strength Rahman and Inden (2012) + 0.25 ml.L-1 SIB, $\mathrm{S}_{3}=3 / 4$ strength Rahman and Inden (2012) + 0.5 ml. . ${ }^{-1}$ SIB, $\mathrm{S}_{4}=3 / 4$ strength Rahman and Inden $(2012)+0.75 \mathrm{ml}^{-L^{-1}} \mathrm{SIB}$ and $\mathrm{S}_{5}=3 / 4$ strength Rahman and Inden $(2012)+1.0 \mathrm{ml} . \mathrm{L}^{-1} \mathrm{SIB}$

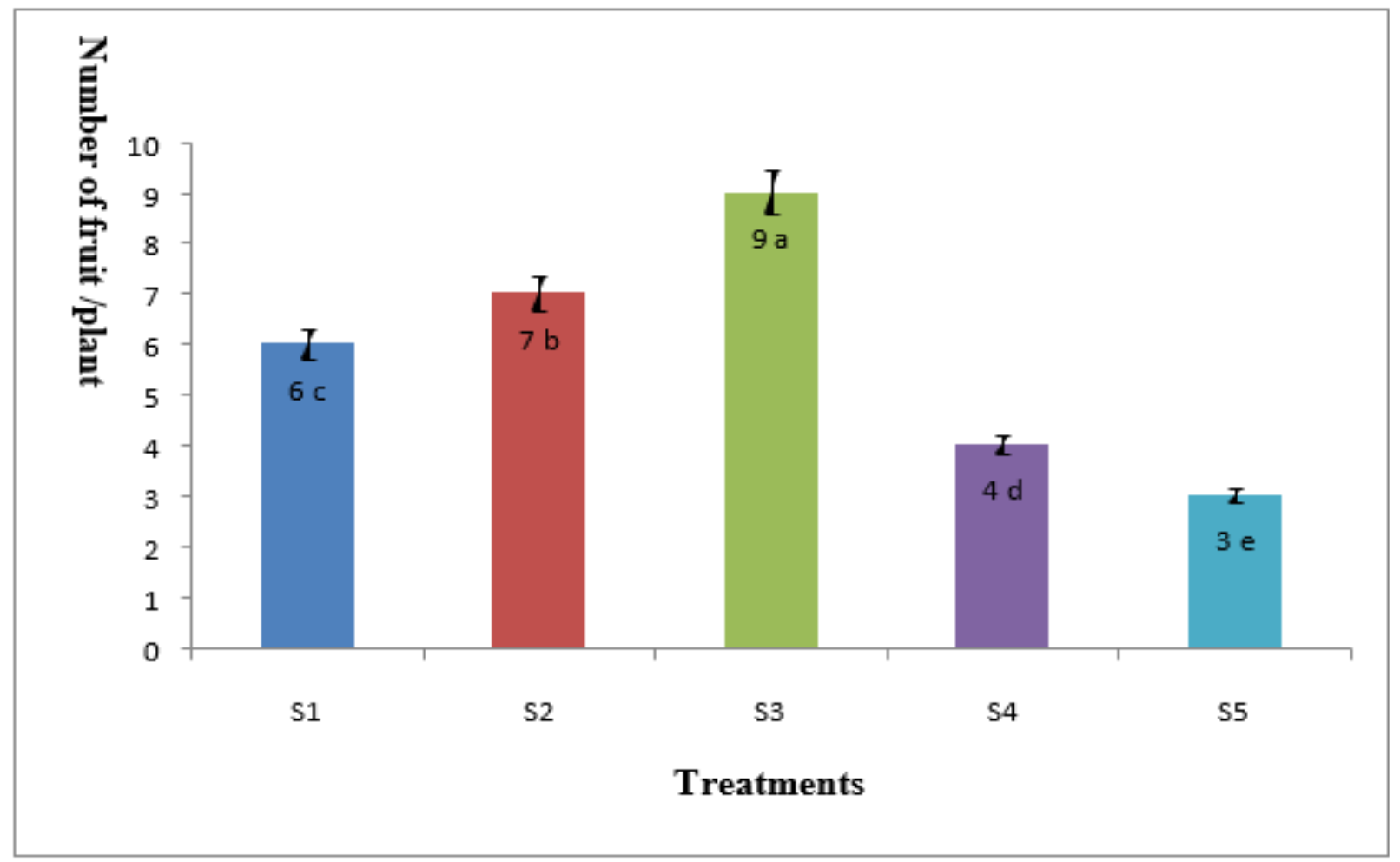

Figure 1: Effect of salt industries byproduct on number of fruits per plant. SIB: Salt industries byproduct, $\mathrm{S}_{1}=3 / 4$ strength Rahman and Inden $(2012)+0 \mathrm{~mL} . \mathrm{L}^{-1} \mathrm{SIB}, \mathrm{S}_{2}=3 / 4$ strength Rahman and Inden $(2012)+0.25 \mathrm{ml} \mathrm{L}^{-1} \mathrm{SIB}, \mathrm{S}_{3}=3 / 4$ strength Rahman and Inden (2012) $+0.5 \mathrm{mlL}^{-1} \mathrm{SIB}$, $\mathrm{S}_{4}=3 / 4$ strength Rahman and Inden $(2012)+0.75 \mathrm{mlL}^{-1} \mathrm{SIB}$ and $\mathrm{S}_{5}=3 / 4$ strength Rahman and Inden $(2012)+1.0 \mathrm{mlL}^{-1} \mathrm{SIB}$. Vertical bars represents the standard error of the means. 


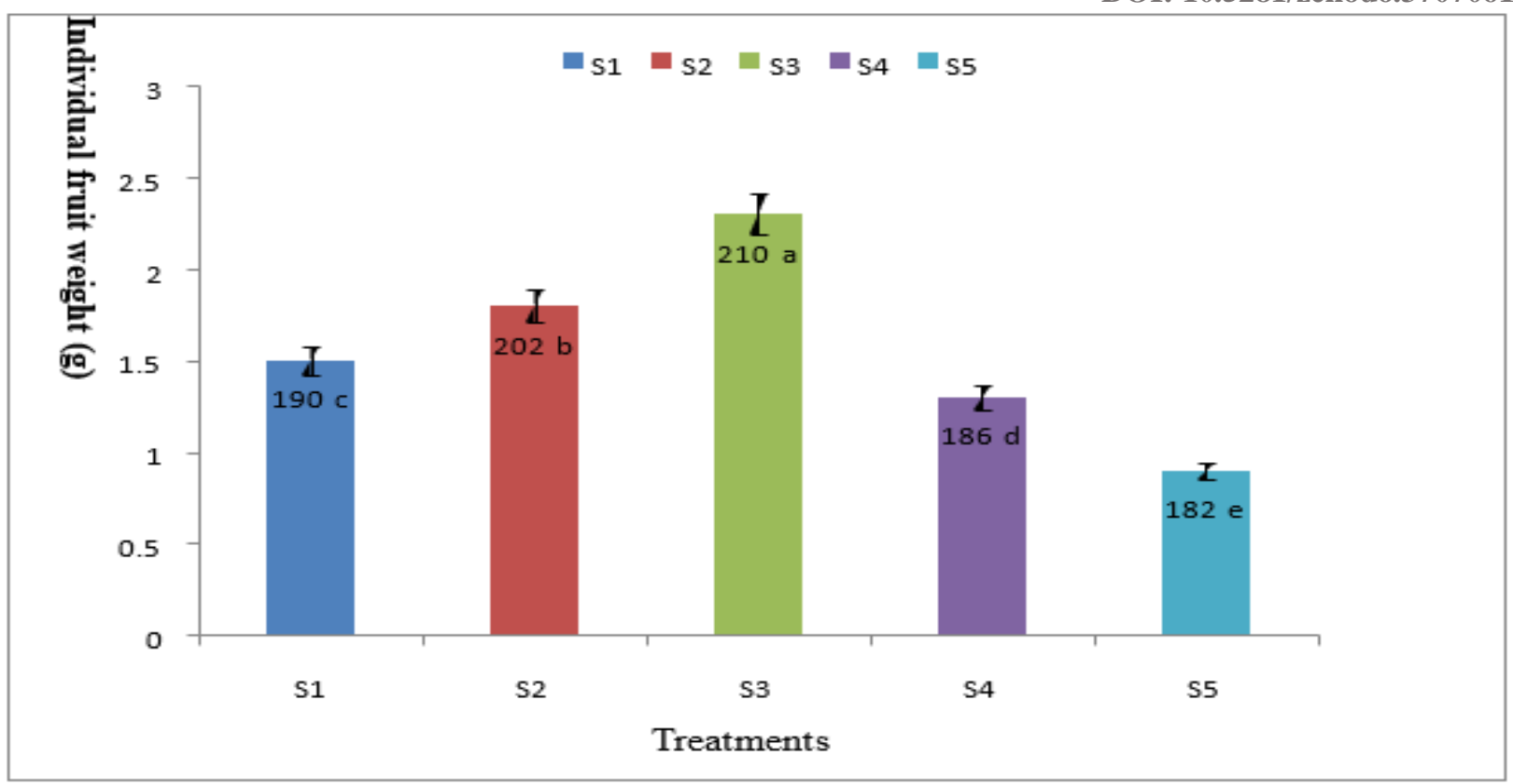

Figure 2: Effect of salt industries byproduct on individual fruit weight (g). SIB: Salt industries byproduct. $\mathrm{S}_{1}=3 / 4$ strength Rahman and Inden $(2012)+0 \mathrm{ml} \cdot \mathrm{L}^{-1} \mathrm{SIB}, \mathrm{S}_{2}=3 / 4$ strength Rahman and Inden (2012) + $0.25 \mathrm{ml} . \mathrm{L}^{-1} \mathrm{SIB}, \mathrm{S}_{3}=3 / 4$ strength Rahman and Inden $(2012)+0.5 \mathrm{ml} . \mathrm{L}^{-1} \mathrm{SIB}, \mathrm{S}_{4}=$ $3 / 4$ strength Rahman and Inden (2012) $+0.75 \mathrm{ml} . \mathrm{L}^{-1} \mathrm{SIB}$ and $\mathrm{S}_{5}=3 / 4$ strength Rahman and Inden $(2012)+1.0 \mathrm{ml} . \mathrm{L}^{-1} \mathrm{SIB}$. Vertical bars represent the standard error of the means.

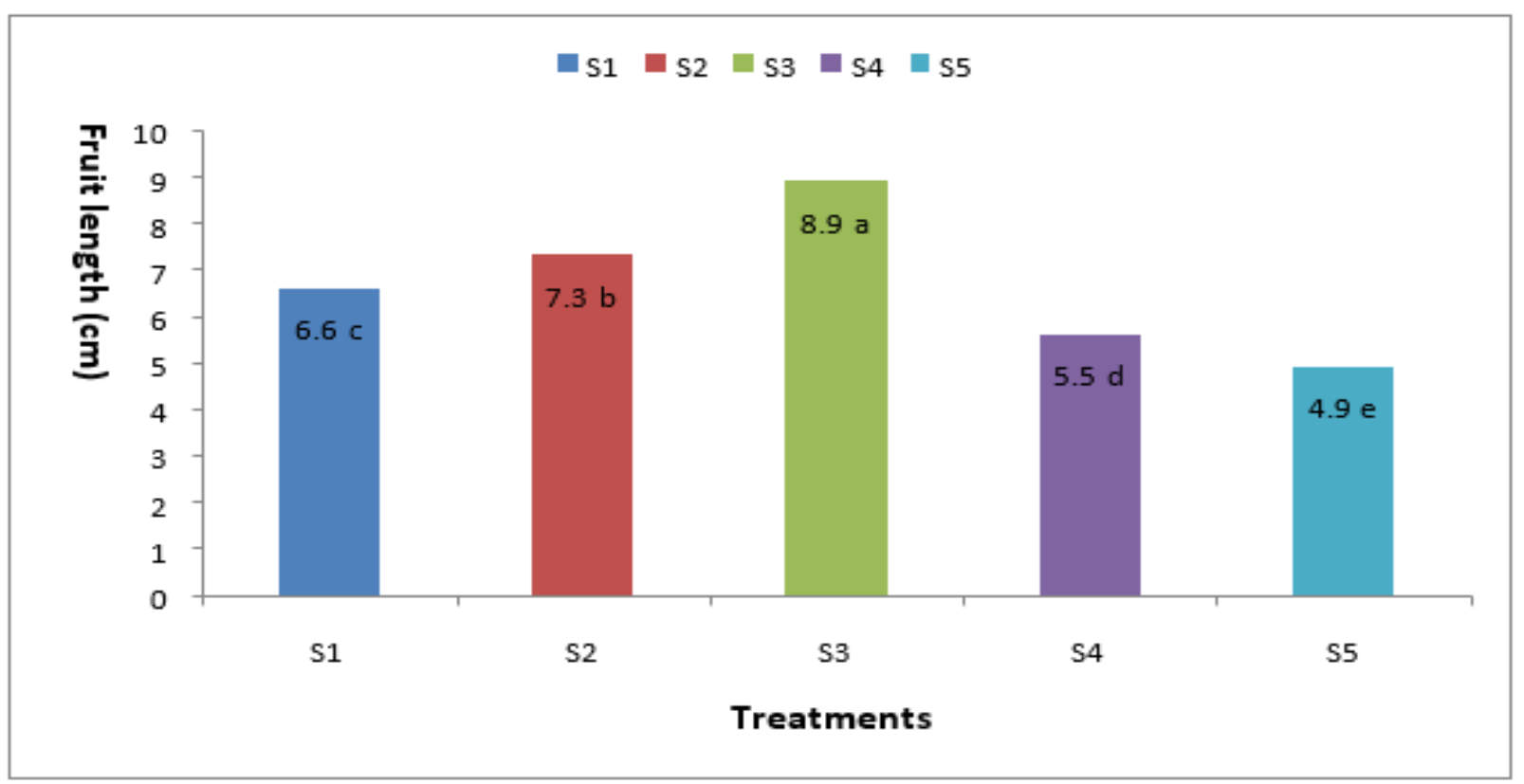

Figure 3: Effect of salt industries byproduct on fruit length $(\mathrm{cm})$. SIB: Salt industries byproduct. $\mathrm{S}_{1}=3 / 4$ strength Rahman and Inden (2012) $+0 \mathrm{ml} . \mathrm{L}^{-1} \mathrm{SIB}, \mathrm{S}_{2}=3 / 4$ strength Rahman and Inden $(2012)+0.25 \mathrm{ml} . \mathrm{L}^{-1} \mathrm{SIB}, \mathrm{S}_{3}=3 / 4$ strength Rahman and Inden $(2012)+0.5 \mathrm{ml} . \mathrm{L}^{-1} \mathrm{SIB}, \mathrm{S}_{4}=3 / 4$ strength Rahman and Inden $(2012)+0.75 \mathrm{ml}^{-1} \mathrm{~L}^{-1} \mathrm{SIB}$ and $\mathrm{S}_{5}=3 / 4$ strength Rahman and Inden $(2012)+1.0 \mathrm{ml} . \mathrm{L}^{-1} \mathrm{SIB}$. Vertical bars represent the standard error of the means. 


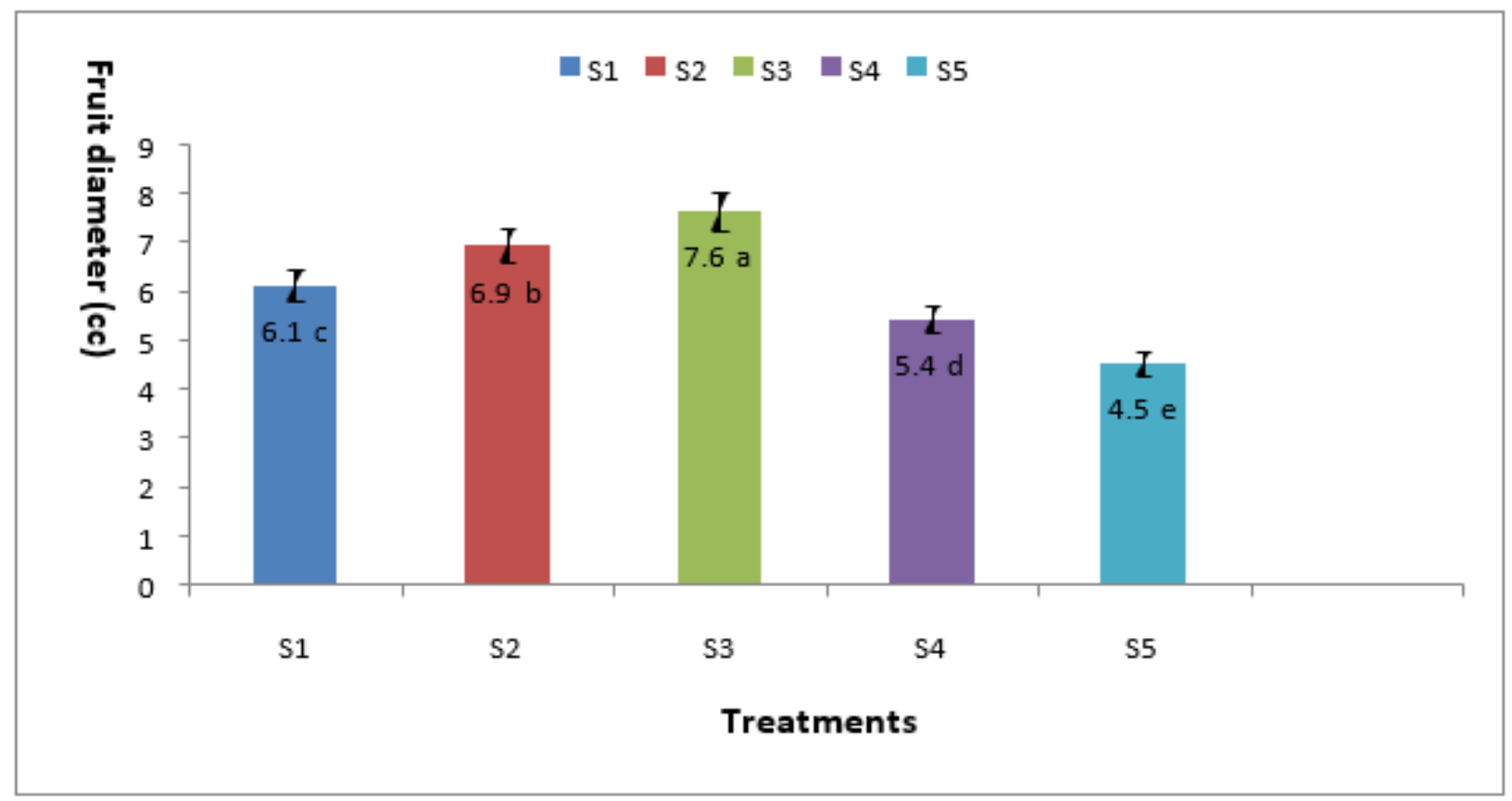

Figure 4: Effect of salt industries byproduct on fruit diameter $(\mathrm{cm})$. SIB: Salt industries byproduct. $\mathrm{S}_{1}=3 / 4$ strength Rahman and Inden (2012) +0 ml.L ${ }^{-1} \mathrm{SIB}, \mathrm{S}_{2}=3 / 4$ strength Rahman and Inden $(2012)+0.25 \mathrm{ml} . \mathrm{L}^{-1} \mathrm{SIB}, \mathrm{S}_{3}=3 / 4$ strength Rahman and Inden $(2012)+0.5 \mathrm{ml} . \mathrm{L}^{-1} \mathrm{SIB}, \mathrm{S}_{4}=3 / 4$ strength Rahman and Inden $(2012)+0.75 \mathrm{ml} . \mathrm{L}^{-1} \mathrm{SIB}$ and $\mathrm{S}_{5}=3 / 4$ strength Rahman and Inden $(2012)+1.0 \mathrm{ml} . \mathrm{L}^{-1} \mathrm{SIB}$. Vertical bars represent the standard error of the means.

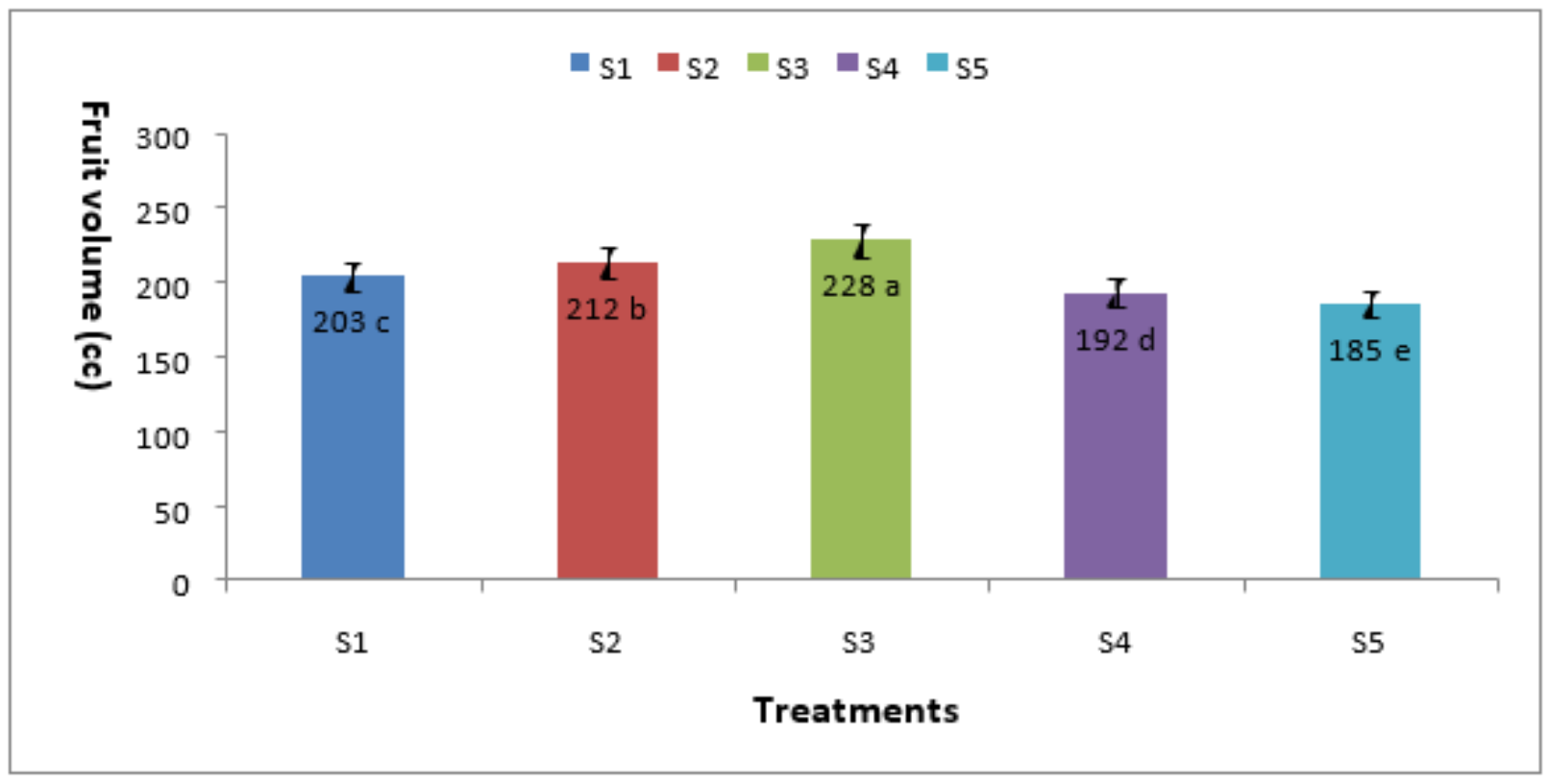

Figure 5: Effect of salt industries byproduct on fruit volume (cc). SIB: Salt industries byproduct. $\mathrm{S}_{1}=3 / 4$ strength Rahman and Inden $(2012)+0 \mathrm{ml} . \mathrm{L}^{-1} \mathrm{SIB}, \mathrm{S}_{2}=3 / 4$ strength Rahman and Inden $(2012)+0.25 \mathrm{ml} . \mathrm{L}^{-1} \mathrm{SIB}, \mathrm{S}_{3}=3 / 4$ strength Rahman and Inden $(2012)+0.5 \mathrm{ml} . \mathrm{L}^{-1} \mathrm{SIB}, \mathrm{S}_{4}=3 / 4$ strength Rahman and Inden (2012) +0.75 ml. $\mathrm{L}^{-1} \mathrm{SIB}$ and $\mathrm{S}_{5}=3 / 4$ strength Rahman and Inden $(2012)+1.0 \mathrm{ml} . \mathrm{L}^{-1} \mathrm{SIB}$. Vertical bars represent the standard error of the means. 


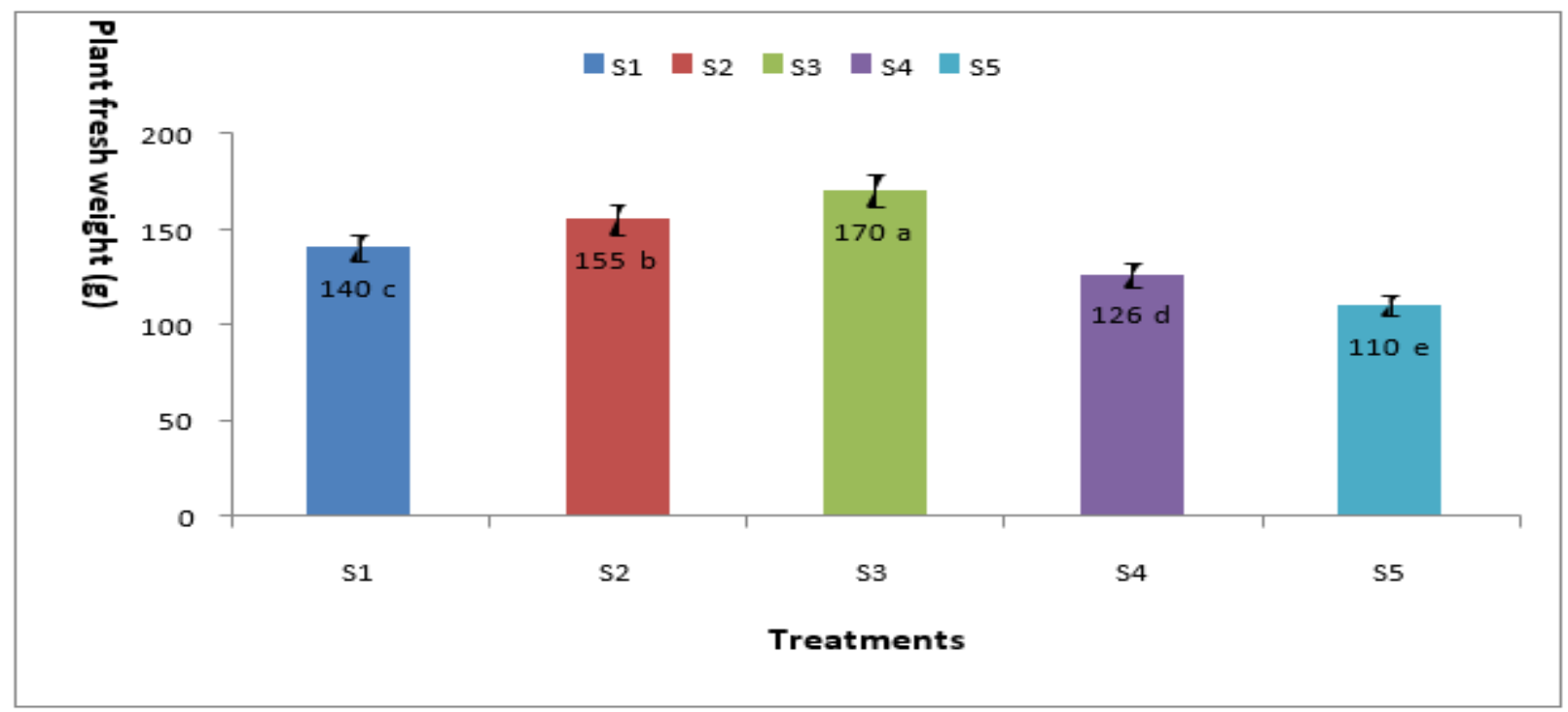

Figure 6. Effect of salt industries byproduct on plant fresh weight (g). SIB: Salt industries byproduct. S1 = 3/4 strength Rahman and Inden (2012) +0 ml.L-1 SIB, S2 = 3/4 strength Rahman and Inden (2012) + 0.25 ml.L-1 SIB, S3 = 3/4 strength Rahman and Inden (2012) + 0.5 ml.L-1 SIB, S4 $=3 / 4$ strength Rahman and Inden (2012) $+0.75 \mathrm{ml} . \mathrm{L}-1 \mathrm{SIB}$ and S5 $=3 / 4$ strength Rahman and Inden $(2012)+1.0$ ml.L-1 SIB. Vertical bars represent the standard error of the means.

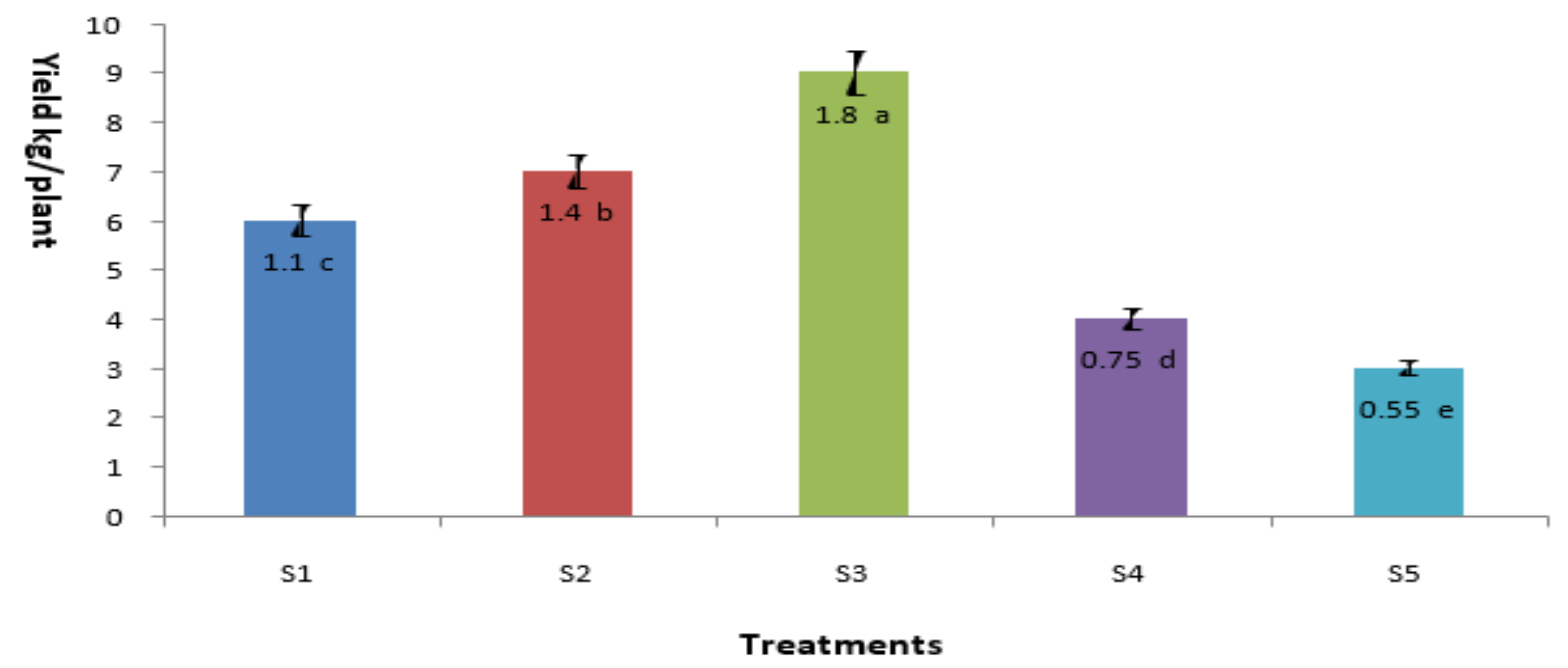

Figure 7. Effect of salt industries byproduct on yield (kg/ plant). SIB: Salt industries byproduct. $\mathrm{S}_{1}$ $=3 / 4$ strength Rahman and Inden (2012) +0 ml. $\mathrm{L}^{-1} \mathrm{SIB}, \mathrm{S}_{2}=3 / 4$ strength Rahman and Inden (2012) $+0.25 \mathrm{ml} . \mathrm{L}^{-1} \mathrm{SIB}, \mathrm{S}_{3}=3 / 4$ strength Rahman and Inden $(2012)+0.5 \mathrm{ml} . \mathrm{L}^{-1} \mathrm{SIB}, \mathrm{S}_{4}=3 / 4$ strength Rahman and Inden (2012) $+0.75 \mathrm{ml} \cdot \mathrm{L}^{-1}$ SIB and $\mathrm{S}_{5}=3 / 4$ strength Rahman and Inden (2012) +1.0 $\mathrm{ml} . \mathrm{L}^{-1} \mathrm{SIB}$. Vertical bars represent the standard error of the means.

\section{Acknowledgment}

The authors extend their gratitude to the Bangladesh Academy of Sciences-United States Department of Agriculture Program in Agricultural and Life Sciences for their contribution towards this research under the project of BAS-USDA-PALS-SAU. 


\section{References}

[1] AVRDC. 1989. Tomato and the pepper production in the tropics. Avrdc., Taiwan. 585p.

[2] Bloch, A. and C.A. Thomson. 1995. Position of the American Dietetic Association: phytochemicals and functional foods. J. Am. Diet. Assoc. 95:493-496. http://dx.doi.org/10.1016/S0002-8223(95)001130-1

[3] Bradbury, M. and R. Ahmad. (1990) The effect of silicon on the growth of Prosopis juliflora growing in saline soil. Plant Soil.125:71-78.

[4] Chartzoulakis, K. andG. Klapaki. 2000. Response of two greenhouse pepper hybrids to $\mathrm{NaCl}$ salinity during different growth stages. Sci. Hortic.86: 247-260.

[5] Chu, Y. F., J. Sun, X. Wu, and R.H. Liu. 2002. Antioxidant and antiproliferative activities of common vegetables. J. Agric. Food Chem.50:6910-6916.

[6] Epstein. E and A.J Bloom .2005. Mineral nutrition of plants: principles and perspectives. 2nd ed, Sinauer Associates, Inc, Sunderland, MA, USA.

[7] Grattan S.R and C.M Grieve. 1999. Salinity mineral nutrient relations in horticultural crops. Sci. Hortic.78: 127-157

[8] Hansen, E.H and D.N. Munns .1988. Effects of $\mathrm{CaSO} 4$ and $\mathrm{NaCl}$ on growth and nitrogen fixation of Leucaena leucocephala. Plant. Soil107: 95-99.

[9] Liang, Y.C., Q.R. Shen, Z.G. Shen, and T.S. Ma. 1996. Effects of silicon on salinity tolerance of two barley cultivars. J. Plant Nutr.19:173-183.

[10] Marcelis L.F.M and L.C.Ho. 1999. Blossom-end rot in relation to growth and calcium content in fruits of sweet pepper (Capsicum annuum L.). J Exp Bot. 50: 357-363.

[11] Navarro, J.M., C.Garrido., M.Carvajal and V. Martinez. 2002. Yield and fruit quality of pepper plants under sulphate and chloride salinity. J. Hortic. Sci. Biotechnol.77: 52-57.

[12] Rahman, M.J. and Inden, H. 2012. Effect of nutrient solution and temperature on capsaicin content and yield contributing characteristics in six sweet pepper (Capsicum annuumL.) cultivars. J. Food. Agric. Environ. 10(1): 524-529.

[13] Sakihama, Y., M.F. Cohen, S.C. Grace, and H. Yamasaki. 2002. Plant phenolic antioxidant and prooxidant activities: Phenolics-induced oxidative damage mediated by metals in plants. Toxicology.177:6780.

[14] Saure, M.C. 2005. Calcium translocation to fleshy fruit: its mechanism and endogenous control. Sci. Hort.105:65-89.

[15] Savvas, D. 2003. Hydroponics: A modern technology supporting the applicationof integrated crop management in greenhouse. J. Food Agric. Environ. 1: 80-86.

[16] Shinohara, Y., K.Tanaka., Y.Suzuk and Y.Yamasaki. 1978. Growing conditionsand quality of vegetables. I. Effects of fertilization and foliar spray treatment on the ascorbic acid content of leaf vegetables. J. Jap. Soc. Hort. Sci. 47(1) 63-70.

[17] Shoemaker, J.S. and Taskey, B.J.E. 1995. Effect of pruning on earliness and growth of capsicum. Practical Horticulture 3: 1097-1118.

[18] Silber, A; M.Bruner; E. Kenig; G.Reshef; H. Zohar; I. Posalski I; H. Yehezkel; D. Shmuel; and B.Aloni.2005. High fertigation frequency and phosphorous level: Effects on summer-grown bell pepper growth and blossom-end rot incidence. Plant Soil. 270: 135-146

[19] Slater. A., N.W. Scott, and M. Fowler. 2003. Plant biotechnology. In: The genetic manipulation of plants. Oxford Univ. Press, Oxford, UK.

[20] Stamatakis, A., N. Papadantonakis, N. Lydakis-Simantiris, P. Kefalas, and D. Savvas. 2003. Effects of silicon, and salinity on fruit yield and quality of tomato grown hydroponically. Acta Hort. 609:141147.

[21] Surh, Y.J. 2002. Anti-tumor promoting potential of selected spice ingredients with oxidative and antiinflammatory activities: a short review. Food Chem. Toxicol.40:1091-1097.

\footnotetext{
*Corresponding author.
}

E-mail address: jrahman 04@ yahoo.com 